\title{
ASPEK IMUNOPATOGENESIS PERIODONTITIS APIKALIS
}

\section{Febrian $^{1}$}

${ }^{1}$ Departemen of Dental Public Health Faculty of Dentistry Andalas University

Affiliasi penulis: ${ }^{1}$ Staff Pengajar Fakultas

Kedokteran Gigi Universitas Andalas

Korespondensi: Febrian

email: drg_febrian@yahoo.com

\section{PENDAHULUAN}

Infeksi pada jaringan periapikal gigi sering disebut juga periodontitis apikalis yang pada umumnya berasal dari infeksi pulpa gigi yang merupakan kelanjutan dari masuknya mikroorganisma kedalam kamar pulpa yang perforasi, gejala ini didahului dengan adanya reaksi inflamasi atau keradangan sebagai reaksi pertahanan tubuh terhadap infeksi. Inflamasi ini dimulai dengan dengan reaksi yang terjadi di dalam kamar pulpa dan kemudian terus ke jaringan periapikal. ${ }^{(1)}$

Masuknya mikroorganisma dalam kamar pulpa gigi setelah melalui proses yang panjang, yang diawali oleh adanya interaksi mikroorganisma pathogen dengan zat yang kariogenik pada permukaan email gigi sehingga menimbulkan karies gigi. Hal ini disebabkan oleh adanya proses demineralisasi email gigi oleh asam hasil metabolisme zat kariogenik oleh mikroorganisma $^{(2)}$

Plak yang merupakan gabungan antara asam, mikroorganisma, sisa makanan dan air liur yang bersifat lengket akan melarutkan permukaan email gigi sehingga membuat lubang. Lubang ini tidak menimbulkan sakit sehingga akan terus membesar. Rasa nyeri akan terasa apabila kerusakan telah mencapai permukaan dentin. Jika tidak rawat dan tambal, lobang gigi akan merusak struktur pulpa gigi.

Mikroorganisma yang paling berperan dalam merusak permukaan gigi adalah streptococcus mutans, hal ini dikemukakan pertama kali oleh JK Clark (1924) ketika mengisolasi sebuah mikroorganisma dari lobang gigi, Dari beberapa penelitian terakhir diketahui bahwa streptococcus mutans bersifat asidogenik dan aciduric serta menghasilkan polisakarida yang bersifat lengket dan mendukung mikroorganisma lain menuju email gigi. ${ }^{(3)}$

Mikroorganisma rongga mulut adalah salah satu yang paling beragam ekologisnya, setidaknya terdapat 350 spesies yang berbeda dan air Liur berisi hingga 100 juta organisme per mililiter. Rongga mulut menyediakan beberapa habitat yang unik bagi kolonisasi bakteri 
antara lain permukaan gigi, permukaan mukosa dan celah-celah gingiva. Kolonisasi micro organisma ini disebut sebagai flora normal. Flora normal memiliki hubungan yang harmonis dengan host. Hubungan ini dapat terganggu apabila ada perubahan pada habitatnya yang akan mempengaruhi stabilitas mikroflora, misalnya xerostomia atau penggunaan antibiotik spektrum luas. Pada beberapa jenis mikroorganisma, perubahan habitat ini dapat membuatnya menjadi mikroorganisma yang patogen sehingga dapat mengakibatkan terjadinya infeksi pada mukosa, terjadinya karies gigi dan penyakit periodontal. ${ }^{(4)}$

Mikroorganisma yang patogen berperan sebagai imunogen yang akan menimbulkan respon imun. Respon imun adalah suatu interaksi seluler tubuh terhadap masuknya antigen yang merupakan upaya tubuh untuk mempertahankan kondisi yang homeostatis. Mekanisme terjadinya keadaan yang patologis pada tubuh yang dilihat dari sudut imunologis dapat diartikan sebagai imunopatologis. ${ }^{(5)}$

\section{PEMBAHASAN}

\section{STRUKTUR JARINGAN PERIAPIKAL}

Jaringan periapikal adalah jaringan yang berada di ujung akar gigi. Jaringan ini menghubungkan antara pulpa gigi dengan jaringan periodontal, keduanya dapat menjadi jalan masuknya mikroorganisma sehingga menimbulkan infeksi pada pada jaringan periapikal.

\section{Struktur Jaringan Periodontal}

Jaringan periodontal adalah jaringan penyangga gigi yang terdiri dari jaringan gusi (gingiva), tulang alveolar, ligamentum periodontal dan cementum yang melekat pada akar gigi. Jaringan periodontal ini mengelilingi dan mendukung gigi secara anatomi dan semua jaringan periodontal menjadi bagian dari jaringan periapikal kecuali gusi (gingiva). Gingiva merupakan suatu jaringan lunak yang terdapat di permukaan rongga mulut yang melekat pada sevikal gigi. Ligamen periodontal merupakan suatu jaringan yang mengelilingi akar gigi dan melekat erat pada gigi dan tulang alveolar. Ligamen periodontal ini terutama terdiri atas serat kolagen yang tersusun secara teratur yang menghubungkan antara gigi dan tulang alveolar. Tulang alveolar merupakan jaringan keras yang memegang gigi. Sementum adalah jaringan terkalsifikasi yang menutupi akar gigi dan melekat pada serat-serat ligamen periodontal gigi. Sementum dibentuk secara berkesinambungan pada permukaan akar gigi yang berkontak dengan ligamen periodontal. ${ }^{(6,7,8)}$ 


\section{Struktur Pulpa Gigi}

Pulpa gigi adalah rongga yang berada didalam gigi yang dibagi atas kamar pulpa yang dan saluran akar. Pulpa gigi kaya dengan Jaringan pembuluh darah, limfatik dan persarafan Dinding pulpa gigi yang terbentuk dari dentin. Unsur utama pembentuk dentin adalah sel odontoblas. Selain odontoblas ada 3 sel yang terdapat didalam dinding pulpa yaitu sel mesenchim, sel fibroblas dan sel fibrocyt. Sel mesenchim ini yang berdiferensiasi dan berprolifersasi menjadi sel odontoblast sedangkan sel fibroblas menjadi unsur dalam pembentukan serat kolagen dan sel fibrocyt bertugas dalam pemeliharaan serat serat kolagen. ${ }^{(9,10)}$

Pembuluh darah arteriola yang merupakan percabangan dari pembuluh darah arteri masuk ke dalam pulpa gigi melalui foramen apikal pada akar gigi. Kapiler arteriola ini akan mensuplai zat gizi yang dibutuhkan oleh sel odontoblas dan sel lain yang ada dalam pulpa gigi. Kemudian darah berpindah ke venula dan kemudian meninggalkan pulpa malalui foramen apikal menuju percabangan pembuluh darah vena. Selain pembuluh darah juga ditemukan pembuluh kapiler limfatik yang keluar dari foramen apikal dan bergabung dengan pembuluh limfatik dari jaringan periodontal lainnya menuju pembuluh limfatik yang lebih besar ${ }^{(10,11)}$
Dari penjelasan struktur Jaringan periapikal dapat diketahui bahwa Jaringan pulpa gigi berhubungan erat dengan jaringan periodontal, baik secara anatomis maupun fungsional. Hubungan secara anatomis berupa hubungan vaskular maupun tubular. Hubungan vaskular dapat berupa hubungan antara pembuluh darah kapiler, di jaringan pulpa dengan di ligamen periodontal.

\section{MANIFESTASI KLINIS DAN PATOLOGIS PERIODONTITIS APIKALIS}

Penyebab utama dalam kelainan jaringan periapikal / periodontitis apikalis adalah hilangnya struktur jaringan permukaan gigi yang menjadi jalan masuk mikroorganisma kedalam pulpa, ini bisa disebabkan oleh karies atau trauma ${ }^{(1)}$. Keadaan ini yang membedakan antara periodontitis apikalis dan periodontitis marginalis. Pada periodontitis marginalis penyebaran infeksi dimulai dari gingiva sedangkan periodontitis apikalis berasal dari pulpa gigi yang diawali oleh adanya karies gigi di permukaan gigi dan kemudian membuat lubang hingga menembus pulpa gigi.

Periodontitis apikalis dapat diklasifikasikan berdasarkan etiologinya, gejala dan gambaran histopatologi. WHO dalam The Application Of The International Clasification Of Desease To Dentistry And 
Stomatology membagi periodontitis yang ada pada periodontitis marginalis apikalis atas. ${ }^{(9,12)}$

1. Acute apical Periodontitis

2. Chronic apikal Periodontitis (apical granuloma)

yaitu spesies prevotella, fusobacterium, lactobacilus, streptococcus, clostridium,

peptostreptococcus, candida, saccharomyces dan pada beberapa

3. Perapikal Abses With Sinus penelitian, species actinomyces dan (dentoalveolar abses with sinus/periodontal abses of pulpa origin with sinus)

enterococcus faecalis selalu ada pada periodontitis apikalis ${ }^{(6,8)}$

Secara klinis klasifikasi periodontitis

4. Perapikal Abses With Sinus to maxila antrum

5. Perapikal Abses With Sinus to nasal cavity

6. Perapikal Abses With Sinus to oral cavity

7. Perapikal Abses With Sinus to skin

8. Perapikal Abses Without Sinus (dental abses without sinus/dentoalveolar abses without sinus, periodontal abses of pulpa origin without sinus)

9. Radikular Cyst (Apical Periodontal cyst/Periapikal Cyst)

10. Apikal dan lateral Cyst

11. Residual Cyst

12. Inflammatory paradental cyst

Keadaan patologis dari periodontitis apikalis ditandai dengan adanya invasi bakteri kedalam saluran akar dan terus menuju ujung akar kemudian keluar melalui foramen menuju jaringan periapikal. Kebanyakan bakteri yang ada dalam periodontitis apikalis hampir sama dengan apikalis sulit dibedakan, kadang kadang antara pemeriksaan histologis dan pemeriksaan klinis sering tertukar. Oleh karena itu pada beberapa penulisan, periodontitis apikalis ini hanya dibagi berdasarkan gejala yang ada yaitu periodontitis apikalis asimtomatik sebagai periodontitis apikalis kronis, periodontitis symtomatik sebagai periodontitis apikalis akut dan periapikal abses.

\section{Periodontitis apikalis akut}

Permulaan awal dari periodontitis apikalis adalah terjadinya reaksi inflamasi pada jaringan periodontal di ujung akar gigi, reaksi ini merupakan respon terhadap iritasi pada jaringan periodontal di ujung akar akibat infeksi yang datang dari saluran akar gigi. Inflamasi ini sangat singkat, ini merupakan awal reaksi dari jaringan periodontal yang masih sehat terhadap infeksi. Secara histologis ditandai dengan adanya sel netrophil dalam lesi dan secara klinis ditandai dengan adanya rasa sakit 
yang menyebar (diffuse), nyeri menguyah dan nyeri saat di perkusi. $(1,6,8,9,10)$

\section{Periodontitis apikalis kronik}

Periodontitis apikalis akut akan berubah menjadi kronik apabila keadaan bertambah memburuk yang ditandai dengan adanya jaringan granulasi dengan munculnya sel limfosit, sel plasma dan makrofag dalam lesi. Pemeriksaan secara radiografis menunjukkan adanya radiolusensi yang diffuse didaerah periapikal gigi. Gejala secara klinis sering tidak dirasakan namun saat di perkusi tetap menimbulkan rasa nyeri. ${ }^{(1,6,8,9,10)}$

\section{Periapikal abses}

Merupakan kelanjutan proses periodontitis apikalis. Terjadinya reaksi inflamasi, menyebabkan sejumlah besar sel darah putih bergerak menuju daerah periapikal terinfeksi dan menyebabkan nekrosis jaringan periodontal sekitarnya sehingga membentuk pus. Akumulasi pus didalam tulang sekitar apek gigi akan menumpuk dan memberikan tekanan kedalam tulang sehingga membentuk saluran pus dalam tulang alveolar yang disebut sebagai sinus. Pada awalnya pus akan dialirkan ke gusi, sehingga gusi yang berada di dekat akar gigi tersebut membengkak. Pus bisa dialirkan ke mukosa mulut, palatum, bawah lidah, kulit dan lain sebagainya, tergantung kepada lokasi gigi yang terkena. Ketika pus mencapai jaringan lunak dapat terjadi pembengkakan wajah. Secara klinis terjadi peningkatan rasa sakit, gigi terasa lebih panjang dari yang lain.

\section{SISTEM IMUN RONGGA MULUT}

Rongga mulut adalah ekosistem yang baik bagi mikroorganisma, diketahui sangat banyak koloni mikroorganisma yang ada di rongga mulut, karena rongga mulut menyediakan habitat yang menguntungkan bagi mikroorganisma tersebut, sisa makanan dan rongga yang tersembunyi menjadi media dan tempat berkembangnya mikroorganisma tersebut. Kondisi ini menjadi berbahaya apabila ekostemnya berubah karena dapat menyebabkan virulensi mikroorganisma tersebut. Virulensi mikroorganisma akan menyebabkan mikroorganisma mampu menembus mukosa maupun jaringan keras gigi yang akan menghantarkan mikroorganisma masuk kesistim sirkulasi dan organ tubuh yang lainnya. ${ }^{(4,13)}$

Walaupun jumlah mikroorganisma yang ada dipermukaan rongga mulut sangat banyak, namun rongga mulut mempunyai mekanisme pertahanan yang sangat kuat dan berlapis yaitu adanya mukosa mulut, adanya jaringan limfosit rongga mulut, adanya saliva serta adanya cairan celah gingiva (gingival crevicular fluid). ${ }^{(4)}$ 


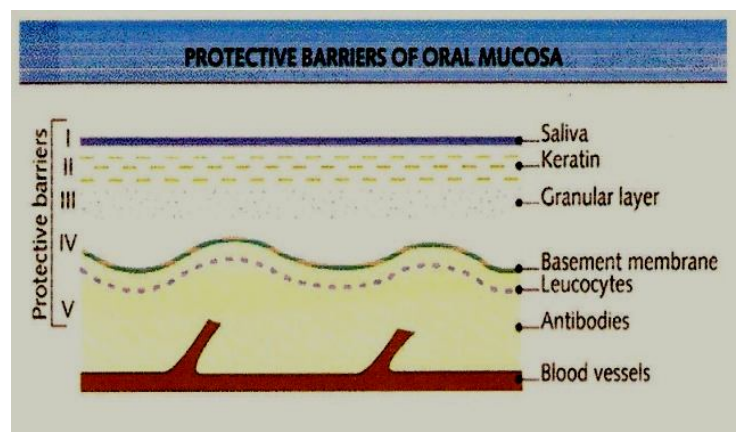

Gambar 1 : Lapisan Pertahanan Mukosa Mulut. (Bagg, 2006)

Untuk dapat mencegah penetrasi mikroorganisma kedalam mukosa mulut ada beberapa lapisan epitel yang menghalanginya antara lain adanya lapisan keratin, lapisan granulasi serta lapisan basal yang sangat kaya dengan sel pembentuk kompleks imun tubuh dan sirkulasi pembuluh darah. Apabila mikroorganisma mampu melewati lapisan diatas maka disinilah terjadi interaksi antigen dan komplek sistem imun tubuh. ${ }^{(4,14)}$

Dalam rongga mulut terdapat 2 jaringan limfosit, ada yang disebut sebagai extra jaringan limfosit dan intra jaringan limfosit. Ekstra jaringan limfosit ini merupakan kapiler jaringan limfosit yang berada pada permukaan superficial dari mukosa mulut, gingiva dan dalam pulpa gigi. Apabila ada ada antigen yang mampu melewati barrier maka antigen akan dibawa oleh sel makrofak yang ada didalam kapiler ini menuju kelenjar limfosit yang ada didalam rongga mulut. ${ }^{(4)}$

Intra jaringan limfosit adalah jaringan limfosit yang tersebar yang ada dirongga mulut. Ada empat kelompok jaringan limfosit yang tersebar dirongga mulut yaitu tonsil palatinal dan lingual, jaringan limfosit kelenjar liur, jaringan limfosit gingiva, sell limfosit yang tersebar di sub mucosa. ${ }^{(4)}$

Saliva merupakan komponen yang penting dalam sistem pertahanan rongga mulut, selain memberikan efek self cleansing yang merupakan proses mekanik dalam membersihkan mikroorganisma pada permukaan mucosa mulut, gigi, gingiva dan lidah, saliva juga mempunyai efek anti microba karena adanya komponen imun didalam saliva. Komponen itu antara lain Ig A, Lysozim, Peroxidase, Lactoferin dan leukosit. Ig A merupakan komponen yang sangat penting dalam mencegah menempelnya mikroorganisma pada permukaan mukosa mulut, gigi, gingiva dan lidah. Ig A dalam saliva diproduksi oleh sel plasma yang ada dalam kelenjar liur. Lysozim dan peroxidase merupakan enzym yang bersifat bacterisidal sedangkan laktoferin merupakan sebuah protein yang bersifat bacteriostatik pada banyak mikroorganisma mulut. Saliva terdapat banyak leukosit (99\% sel PMN) yang keluar dari sirkulasi pembuluh darah menuju rongga mulut melalui celah gusi (crevice gingiva). ${ }^{(4,7)}$ 


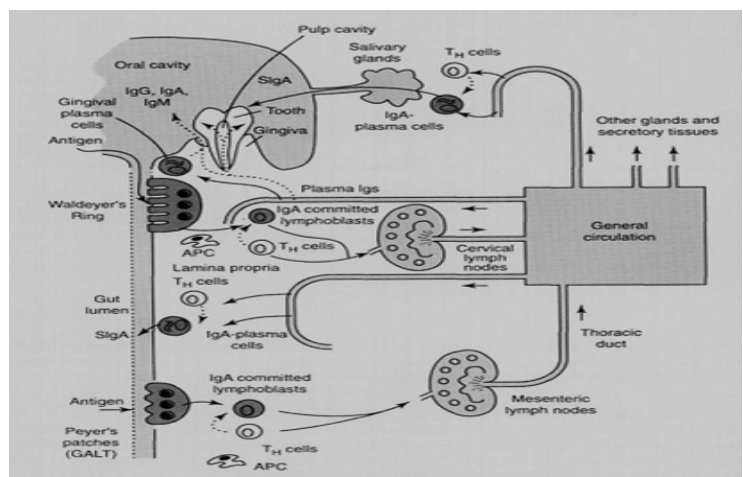

Gambar 2 : Common Mucosal Immune System And Salivary Immunity. (Russel, 1999)

Cairan celah gingiva merupakan cairan yang keluar melalui gingiva epitelial junction dan mengalir ke rongga mulut. Cairan ini sering disebut Gingival Crevicular Fluid (GCF). Selain sel lekosit ternyata dalam gingival Crevicular Fluid terdapat banyak komponen imun antara lain Ig M, Ig G, Ig A, Komplemen, Limfosit T Dan Limfosit B, Protein, Enzym (lysozim, protease and collagenase) dan Makrofak. ${ }^{(4)}$

\section{SISTEM IMUN PULPA GIGI DAN JARINGAN PERIAPIKAL}

Penyebab utama peradangan pulpa adalah masuk bakteri atau imunogen yang dikeluarkan bakteri ke dalam pulpa gigi. Bakteri dapat masuk ke pulpa gigi apabila adanya karies yang sangat dalam, fraktur gigi yang mencapai pulpa, anomali dentin, atau perforasi pulpa akibat tindak prosedur restorasi gigi. ${ }^{(8,15)}$

Karies gigi adalah penyakit yang disebabkan oleh mikroorganisma yang mempengaruhi kalsifikasi lapisan gigi dan pulpa. Karies gigi muncul karena adanya bakteri spesifik yang menempel pada permukaan gigi. Karies gigi akan membuat kavitas pada permukaan gigi dan masuk lebih dalam sehingga mengiritasi pulpa dan akhirnya menyebabkan peradangan pada pulpa $^{(2)}$

\section{Respon Pulpa Tehadap Peradangan}

Faktor etiologi utama untuk peradangan pulpa adalah masuk bakteri atau imunogen yang dikeluarkan oleh bakteri ke dalam pulpa gigi. Bakteri dapat masuk ke pulpa gigi apabila adanya karies yang sudah sangat dalam, fraktur gigi yang mencapai pulpa, anomali dentin, atau perforasi pulpa akibat tindak prosedur restorasi gigi. ${ }^{(15)}$

Respon terhadap mikroorganisma diawali pada saat bakteri menyerang email dan mulai masuk kedalam dentin, pada saat itu terjadi perubahan dalam pulpa berupa timbulnya reaksi pada odontoblasts. Reaksi odontoblas ini merangsang pembentukan dentin reaksioner/tertier. ${ }^{(2,9,10)}$

Respon pulpa terhadap bakteri sangat bervariasi ini semua tergantung pada proses perkembangan karies, Karies dapat berkembang dengan cepat (karies akut), dengan perlahan-lahan (karies kronis), atau berhenti (karies arrested), namun dalam perjalanannya, proses perkembangan karies ini sering berubah ubah, ada periode yang terkadang sangat aktif sekali dan ada terkadang periodenya sangat tenang. Trowbridge (2002) ada beberapa faktor 
yang berpengaruh dalam menentukan proteolitik yang dapat menghancurkan tingkat serangan karies yaitu : ${ }^{(10)}$

1. Usia (kebiasaan makan dan email dan dentin. Produk ini disebut juga kematangan kristal hidroxy apatit)

sebagai bakteri endotoksin yang merupakan

2. Komposisi jumlah partikel fluor pada gigi

3. Sifat dan jenis bakteri yang ada pada lesi karies

4. Jumlah aliran saliva ( pasien xerostomia mudah terjadi rampan karies)

5. Antibakteri yang ada dalam salifa (IgA, Lisozym)

6. Kebersihan mulut

7. Komsumsi makanan yang cariogenik (carbohydrat refine)

8. Faktor penghambat karies dalam makanan (calcium, phospat)

Perkembangan mikroorganisma

karies sangat tergantung kepada kondisi lingkungannya dan ketersediaan makanan baginya, oleh sebab itu beberapa mikroorganisma yang ada pada karies email berbeda dengan karies dentin contohnya spesies Lactobacilus hanya berkembang pada rongga kavitas yang dalam dan $\mathrm{pH}$ rendah, oleh sebab itu spesies mikroorganisma ini disebut juga sebagai organisma aciduric yang hanya dapat berkembang pada karies dentin dan suasana asam. ${ }^{(9,10)}$

Produk metabolisme mikroorganisma rongga mulut berupa asam dan enzim imunogen. Imunogen yang ada pada dentin dapat menyebabkan keradangan pada pulpa. Bakteri imunogen ini menyebar dari lesi karies dentin ke pulpa melalui tubulus dentin kemudian ditangkap dan diproses oleh APC (antigen Presenting cell) yang akan mengaktifkan sistem imun. Masuknya bakteri imunogen kedalam pulpa akan menyebabkan inflamasi akut dan akhirnya terjadi infeksi dan nekrosis pada pulpa. $(8,9,10)$

Respon awal pulpa terhadap masuknya antigen kedalam tubulus dentin adalah terjadinya infiltrasi sel polymorphonuclear neutrofil (PMNs) dan monocytes. Kuatnya infiltrasi sel tersebut kedalam pulpa menyebabkan meningkatnya kondisi infeksi yang akan mengaktifkan respon imun spesifik yaitu aktifnya sel $\mathrm{T}$ helper, $\mathrm{T}$ sitotoksik dan sel B, Tahap selanjutnya, sel plasma akan memproduksi antibodi. Apabila mekanisme ini tidak mampu untuk menghilangkan infeksi maka jaringan lunak kemudian hancur dan mulai terbentuk jaringan nekrotik dan pus dalam pulpa dan akhirnya mengakibatkan menjadi necrosis pulpa secara keseluruhan. ${ }^{(8,9,10,14)}$

Respon pulpa terhadap inflamasi di identifikasi dengan cara imunohistokimia, jumlah sel limfosit $\mathrm{B}$ dan Limfosit $\mathrm{T}$ di 
jaringan pulpa gigi yang diduga sebagai pulpitis reversibel atau ireversibel akan meningkat sesuai dengan beratnya gejala klinis (16). Jumlah sel limfosit $\mathrm{T}$ meningkat pada karies dentin dangkal namun sel Limfosit B akan meningkat pada karies dentin yang dalam. Pada pulpitis irreversible ditemukan adanya sel limfosit T CD8 citotoksik ${ }^{(17,18)}$.

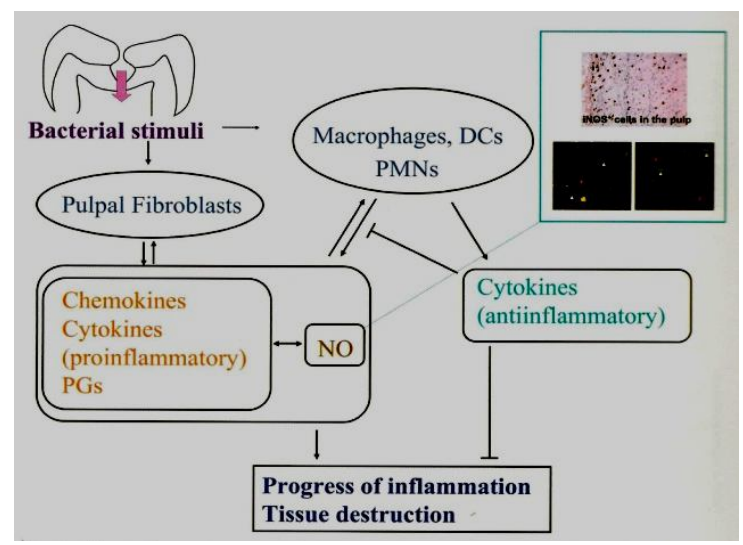

Gambar 3 : Proses Inflamasi Pulpa Gigi (Orstavik, 2008)

\section{Sel-Sel Dalam Sistem Imun Pulpa}

Jaringan dalam pulpa gigi mirip dengan jaringan ikat, sel sel yang ditemukan pada pulpa gigi pada dasarnya sama dengan jaringan ikat dan mempunyai imunokompeten tehadap rangsangan berbahaya, termasuk bakteri. Sebagai contoh pada pulpa normal ditemukannya APC sel dendritik, adanya sel makrofag, sejumlah kecil sel limfosit $\mathrm{T}$, terutama di pembuluh darah, sebaliknya sel limfosit B dan sel plasma tidak terdeteksi dalam pulpa. ${ }^{(14)}$

\section{Limfosit}

Sel limfosit merupakan sel dari sistem imun, yang mengenali antigen dengan cara yang spesifik. Limfosit secara umum dibagi menjadi dua kelompok besar, yaitu, Limfosit B dan Limfosit T. Limfosit B menghasilkan antibodi terhadap antigen tertentu hasil dari proliferasi dan maturasi sel plasma. Limfosit $\mathrm{T}$ dapat dibagi menjadi sel T helper CD4 dan sel T sitotoksik CD8. Aktivasi Limfosit T CD4 memainkan peran penting dalam respon imun karena adanya ikatan antigen dengan $\mathrm{T}$ sel reseptor (TCR). Pada saat aktivasi tersebut, mereka mengeluarkan beberapa sitokin, yang merupakan sekelompok molekul biologis aktif yang mengatur intensitas atau lama respon imun dengan cara merangsang atau menghambat aksi dari berbagai sel target. Berdasarkan sitokin yang dihasilkannya, $\mathrm{T}$ helper CD4 dibagi atas sel Th0,Th1,Th2 dan Th3. Sel Th1 menghasilkan interleukin (IL2) dan interferon gamma (IFNy) yang berperan dalam aktivasi makrofag, sedangkan sel Th2 memproduksi sitokin seperti IL-4, IL-5, dan IL-6 yang merangsang proliferasi dan diferensiasi Limfosit B. ${ }^{(19,20)}$

Pulpa yang tidak mengalami inflamasi tidak terdapat sel limfosit (10), namun dalam beberapa penelitian terakhir menyatakan bahwa sel limfosit merupakan sel yang selalu ada pada pulpa normal. 
Dengan cara immunohistochemistri dengan menggunakan monoclonal antibodi, untuk pertama kalinya mendeteksi sel CD4 dan CD8 limfosit T pada pulpa normal $(14,16)$. Dengan menggunakan Cytometry analisis terhadap sel dari pulpa normal ditemukan sel CD4 dan CD8 namun jumlah CD4 lebih banyak pada CD8 (21), bahkan juga ditemukan adanya sel $\mathrm{T}$ CD45RO pada pulpa nomal manusia. ${ }^{(18)}$

Berbeda dengan sel T, Sel Limfosit B pada beberapa penelitian gagal ditemukan dengan cara imunohistokimia menggunakan antiserum terhadap immunoglobulin pada pulpa normal begitu juga dengan menggunakan monoklonal antibodi melawan sel B limfosit. ${ }^{(14,17,21)}$

\section{Makrofag}

Sel Makrofag merupakan sel fagosit mononuklear yang berarti sel fagosit yang berinti satu dengan prekusor sel monosit. Sel monosit ini berasal dari sel premonosit di sumsum tulang. Sel ini hanya 5 sampai $10 \%$ yang dilepas ke sirkulasi pembuluh darah dan apabila sel ini keluar dari sirkulasi ia akan berubah menjadi makrofak dan dapat menetap sampai berbulan bulan di jaringan. ${ }^{(19)}$

Bermacam macam jenis makrofag ditemukan dijaringan. Sel makrofak ini dibedakan berdasarkan morfologi, fenotip dan sifat fungsional fagositiknya. Setiap jaringan yang ditempati oleh makrofak didasarkan kepada karakteristik makrofak apa yang dibutuhkan oleh lingkungan tersebut. Sel dendrit tidak dianggap sebagai Mononuklear Phagocyte System (MPS) karena mempunyai aktivitas fagositik lemah. Rangsangan inflamasi akan menyebabkan aktivasi dan diferensiasi dari sel makrofak. ${ }^{(22,23,24)}$

Makrofak banyak terdapat pada jaringan ikat sekitar pembuluh darah, pada paru yang dinamakan sebagai sel makrofag alveolar, pada kulit yang dinamakan sebagai sel langerhans, pada hati yang dinamakan sel Kupffer, pada ginjal yang dinamakan sebagai sel mesangial, pada otal yang dinamakan sebagai sel glia, pada tulang yang dinamakan sebagai sel osteoklas dan juga terdapat limfonodus dan sel limfa. ${ }^{(19)}$

Makrofak merupakan sel fagosit utama yang akan menelan benda asing, antigen, sel yang sudah mati dan rusak. Makrofak juga menghasilkan beberapa zat aktif biologis antara lain microbicidal enzym dan reaktive oxigen spesies, beberapa cytokin yaitu IL 1, IL 6 dan TNF, beberapa growth faktor bagi sel sel fibroblas dan sel endothelial yang berguna bagi penyembuhan luka. Selain itu makrofag juga berfungsi mengaktifkan sel limfosit $\mathrm{T}$ dimana makrofag bertindak sebagai antigen processing sel (APC) yang akan memproses setiap antigen yang masuk 
menjadi peptida peptida, kemudian menjadi fragmen peptida. Berdasarkan berikatan dengan MHC klas II. Ikatan lokasinya sel ini dibagi atas 1. sel dendrit peptida dan MHC Klas II ini akan non organ limfoid yang banyak terdapat di dipresentasikan ke permukaan sel makrofak jaringan ikat, 2. sel dendrit di organ limfoid yang kemudian akan dikenali oleh $\mathrm{T}$ sel yang terdapat di kelenjar limfoid dan limpa, reseptor Limfosit ${ }^{(14,19) .}$

Makrofak terdapat juga pada pulpa normal manusia, keberadaannya telah diamati melalui microskop elektron. Sel makrofag ini terlihat dengan bentuk yang berbeda beda, ada yang terlihat bulat, oval, lonjong atau dendrit. ${ }^{(9,10,25)}$

Penelitian Imunohistokimia terakhir mengungkapkan adanya molekul permukaan dari makrofak dalam pulpa gigi. Molekul permukaannya merupakan MHC klas II dan mempunyai karakteristik yang sama dengan yang ada pada sel dendrit. Pada beberapa penelitian terdapat berbagai macam kombinasi marker permukaan yang dikenali dengan dengan menggunakan monoklonal antibodi antara lain CD 14, CD 11c, CD68, HLA-DQ, HLA-DR, dan faktor XIIIa ${ }^{(14)}$.

\section{a. Sel dendrit}

Sel Dendrit adalah sel yang berasal hematopoietic dengan ciri morfologi sangat dendritik, berfungsi sebagai sel APC dengan ekspresi molekul permukaan MHC klas II. Sel dendrit juga merupakan fagositik yang lemah namun sangat efektif dalam mendeteksi dan menangkap protein antigen dan kemudian mengolahnya 3. sel dendrit dalam sirkulasi pembuluh darah dan pembuluh limfa. ${ }^{(14,19)}$

Setelah mengambil antigen, sel dendrit non organ limfoid akan bermigrasi ke jaringan limfoid. Selama bermigrasi terjadi sintesa molekul MHC klas II dan proses degradasi protein antigen menjadi fragmen peptida. Pada saat sampai di Jaringan limfoid fragmen peptida ini akan berikatan dengan molekul MHC klas II kemudian akan di presentasikan ke permukaan sel dendrit untuk dikenali oleh TCR limfosit $\mathrm{T}^{(19)}$. Sel dendrit ini sangat banyak terlibat dalam respon imun primer yang menstimulasi Th 0 limfosit T CD4 ( Limfosit T Naive). ${ }^{(10,14)}$

Dengan bentuk khas dendritik, pada pulpa gigi, sel dendrit banyak terkonsentrasi di pinggir pulpa gigi dan terlihat di bawah lapisan sel odontoblas. Lokasi ini merupakan lokasi strategis, dimana dilokasi inilah terdapat kesempatan terbesar untuk bertemu antigen, karena antigen yang masuk kedalam pulpa melalui tubulus dentin dan turun menuju lapisan sel odontoblas..$^{(8,9,10,14)}$

Sel dendrit pada pulpa menunjukkan heterogenitas, pada beberapa penelitian 
dengan menggunakan monoklonal antibodi menunjukkan ada berbagai kombinasi marker yang sama dengan yang ada pada makrofak $^{(14)}$

\section{Respon Jaringan Periapikal Terhadap Peradangan}

Pemaparan mikroorganisma dan produk yang dihasilkannya kedalam pulpa akan memicu respon inflamasi pada pulpa. Reaksi inflamasi akibat karies kedalam pulpa biasanya didiagnosis sebagai pulpitis dengan tanda nyeri hebat yang datang dari dalam pulpa akibat besarnya migrasi sel sel radang kedalam pulpa. Perkembangan inflamasi pulpa gigi yang meluas kedaerah periapikal yang didiagnosis sebagai periodontitis apikalis ditandai dengan hancurnya tulang alveolar sekitar jaringan meradang dan meningkatnya sel radang di kawasan periapikal gigi sebagai akibat adanya respon imun dan terjadi resorbsi tulang alveolar, resorbsi sementum, resorbsi dentin yang berada sekitar daerah yang inflamasi yang berakibat berkurangnya stabilitas gigi. $(9,10,26)$

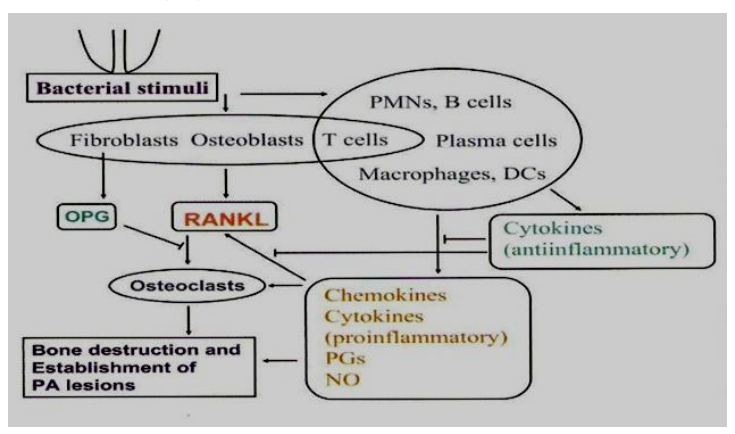

Gambar 4 : Proses Inflamasi Jaringan Periapikal Gigi (Orstavik, 2008)
Respon imun pada area periapikal dipandang sebagai garis pertahanan kedua, respon awal dari sistem pertahanan di jaringan periapikal adalah infiltrasi sel PMN dan diikuti dengan meningkatnya jumlah sel osteoklas. Secara klinis adanya rasa sakit saat menggigit atau rasa sakit saat gigi di perkusi dan secara radiografis terlihat periapikal radiolusent ${ }^{(9,10)}$

Elemen yang ada pada area inflamasi di daerah periapikal adalah sel PMN, makrofag, Limfosit $\mathrm{T}$ dan limfosit $\mathrm{B}$, sel mast, osteoklas, osteoblas, fibroblas, sel epitel rest dan adanya kemokin yang mengatur terjadinya reaksi inflamasi tersebut. Jumlah Sel PMN paling banyak, sel makrofag dan sel limfosit meningkat jumlahnya dari normal, sel limfosit jumlahnya lebih banyak dari sel B, dan pada infeksi kronis limfosit $\mathrm{T}$ supressor lebih banyak dari pada T helper. ${ }^{(8,9,10,14,26)}$

Keluarnya kemokin ini distimulasi oleh mikroorganisma dan protein dentin spesifik terhadap sel yang berperan dalam sistem imun seperti makrofak, sel osteoklas, sel neutrofil, sel fibroblas. Kemokin ini berfungsi mengaktifkan proses kemotaksis sel PMN, diferensiasi dan proliferasi sel osteoklas, demineralisisi tulang alveolar, dentin dan sementum. ${ }^{(26)}$

Penelitian terhadap MIP-3 / CCL20 yang didistribusikan oleh makrofak dan reseptor CCR6 pada sel $\mathrm{T}$ limfosit yang 
mengikat CCL20 banyak terdapat pada daerah lesi yang meradang, keduanya (CCL20 dan CCR6) jarang terdeteksi pada pulpa normal. ${ }^{(26,27)}$

Pada beberapa penelitian terbukti bahwa MCP1 berperan penting dalam migrasi sel PMN ke lokasi inflamasi periapikal ${ }^{(29)}$ dan protein spesifik dentin mampu menstimulasi migrasi neutrofil ${ }^{(30)}$. Infeksi mikroorganisma Porphimonas endodotalis, $\mathrm{P}$ gingivalis, $\mathrm{P}$ intermedia mampu mendorong fibroblas dan osteoblast menghasilkan kemokin IL8/CXCL8 dan mendorong neurofil menghasilkan MP1/CCL3 dan MP1/CCL4 (31) , mendorong makrofag menghasilkan KC/CXCL1. ${ }^{(32)}$

Selain kemokin, Prostaglandin (PG) merupakan bagian dari enzim cylooxigenase hasil metabolisme dari asam arakhidonat serta Nitric Oxide (NO) yang merupakan gas yang dihasilkan oleh interaksi (oxygen Reactive) berbagai molekul dan spesies diduga berpengaruh dalam mempercepat proses inflamasi. Beberapa penelitian dengan tikus membuktikan adanya hubungan PG dengan meningkatnya akvitas inflamasi periapikal gigi. ${ }^{(8)}$

Periodontitis apikalis kronis sering disebut sebagai periapikal granuloma karena terdapatnya jaringan inflamasi ganulomatosa di perapikal gigi sebagai akibat sel sel radang yang diselubungi oleh kapsul fibrosa, dan dapat berkembang menjadi kista periapikal dengan karakreristik adanya lapisan epitel berongga. Berdasarkan penelitian secara imunohistochemistry menunjukkan adanya kemokin IL8, MIP1, IP10,MCP1, Rantes dan reseptor CCR3, CCR5 CXCR3 pada periapikal granuloma ${ }^{(33)}$ dan menunjukkan peningkatan IP10, MCP1, Rantes dan reseptor CCR3, CCR5, CXCR1, CXCR3 pada periapikal kista. ${ }^{(34)}$

Beberapa penelitian terhadap lesi periapikal, terdapat sel imunoglobulin didalamnya, Ig G paling banyak (70\%), IgA (14\%), IgE (10\%), IgM (4\%). Antibodi yang diproduksi ini reaktif terhadap mikroorganisma Prevotella intermedia, P endodontalis, $\mathrm{P}$ gingivalis, $\mathrm{P}$ mikro, Actinomyces israelii, Staphylococcus intermedius, dan Fusobacterium nucleatum. Dan disimpulkan bahwa antigen yang masuk ke saluran akar mampu merangsang respons antibodi sistemik. ${ }^{(8)}$

Pada beberapa penelitian terdapat juga sitokin anti inflamasi yang menghambat kerja dari citokin pro inflamasi. IL 10 merupakan tipe citokin anti inflamasi. Pada penelitian dengan tikus menunjukkan IL10 dapat menghambat kerja citokin pro inflamasi ketika IL 10 di induksikan kedalam jaringan periapikal yang mengalami inflamasi. ${ }^{(8)}$ 
MEDIATOR DALAM INFLAMASI JARINGAN PERIAPIKAL

\section{PULPA}

Inflamasi periapikal ditandai oleh migrasi sel polymorphonuclear leukosit, monosit, limfosit, plasma dan sel mast, dan osteoblast dan osteoklas, untuk mengaktivasi sel tersebut bermigrasi ke daerah inflamasi diperlukan mediator. $(9,10,26)$

Mediator ini adalah kemokin. Sinyal dari kemokin diterjemahkan oleh reseptor spesifik yang ada pada sel sel imun untuk memulai aktivitas sehingga menimbulkan respon selular, antara lain kemotaksis dan aktivasi sel inflamasi dan sel-sel tulang. Selain itu sinyal kemokin juga menyebabkan proses biologis lainnya seperti angiogenesis, proliferasi sel, apoptosis, tumor metastatis. ${ }^{(19)}$

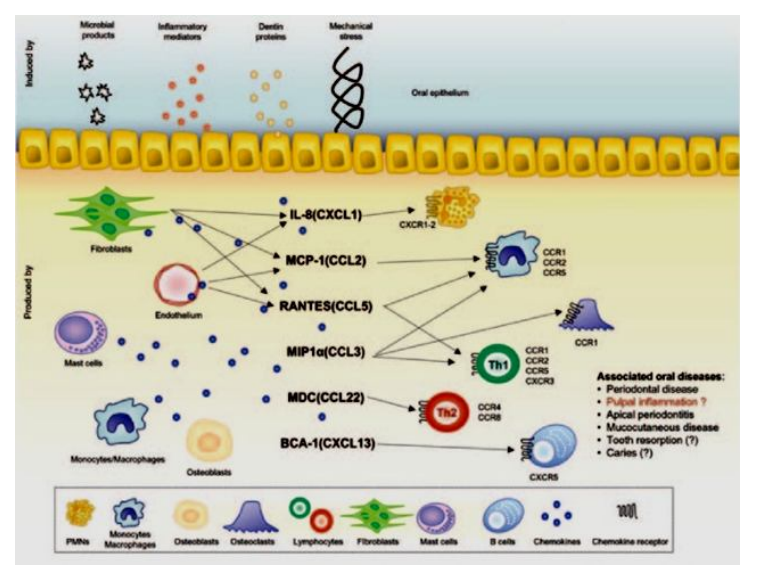

Gambar 5 : Kemokin reseptor di jaringan lunak rongga mulut ( Silva, 2007)

Kemokin di produksi oleh berbagai macam sel seperti sel fibroblast, sel endotel, sel mast, sel osteoblas, sel makrofag. Sinyal dari kemokin akan ditangkap oleh reseptor kemokin yang terdapat pada sel PMN, Makrofag, Sel osteoklast, Sel Limfosit T, sel limfosit B. Beberapa kemokin yang telah diketahui penyebab migrasi sel PMN ke lokasi inflamasi, Interleukin (IL), Tumor Necrosis Faktor (TNF), Bakteri lipopolisaccharida (LPS). ${ }^{(9,10,26)}$

Kemokin merupakan protein superfamili yang mempunyai rantai asam amino (sistein) yang berpasangan dengan dua rantai sulfida. Penamaan kemokin berdasarkan susunan sisteinnya dan diklasifikasikan menjadi 4 yaitu kemokin a (CXC) seperti IL8 yang bereaksi terutama dengan netrofil, kemokin b (CC) seperti Monosit Chemoactractan Protein1 (MCP1), Macrophage Inflammatory Protein1 (MIP1), Regulated and normal $\mathrm{T}$ expressed and secreted (Rantes) bereaksi dengan dengan monosit, limfosit sel leukosit kecuali netrofil, Kemokin g (C) seperti Limfolaktin dan kemokin sistein CX3C. Reseptor kemokin penamaannya didasarkan tatanama kemokinnya ${ }^{(19,26)}$

Beberapa reseptor kemokin yang telah diketahui untuk penyakit dalam rongga mulut seperti yang terdapat pada makrofag yaitu CCR1, CCR2 dan CCR5 menerima kemokin yang dihasilkan oleh sel fibroblast, sel endotel, sel makrofag, sel mast dan sel osteoblast seperti MIP1 (CCL3), RANTES (CCL5), MCP1 (CCL2). Reseptor kemokin pada osteoklas adalah 
CCR1, reseptor kemokin Th1 limfosit $\mathrm{T}$ adalah CCR1, CCR2, CCR5 dan CXCR3, reseptor kemokin $\mathrm{Th} 2$ limfosit $\mathrm{T}$ adalah CCR4, CCR8, reseptor kemokin netrofil CXCR1 dan CXCR2, reseptor kemokin sel $\mathrm{B}$ adalah CXCR5 ${ }^{(26,35,34,36,33)}$

Selain reseptor kemokin yang terdapat pada tulang, untuk menjaga keseimbangan integritas jaringan tulang antara reposisi oleh osteoklas dan deposisi oleh osteoklas, terdapat juga mekanisma lain yang mendorong tejadinya reposisi dan deposisi pada tulang yaitu TNF receptor, Reseptor aktivator of nuklear factor (RANK), Osteoprotegerin (OPG), Ligan RANK (RANKL). RANK terdapat pada prekursor osteoklas dan osteoklas mature, sementara RANKL terdapat pada osteoblast. Interaksi antara RANK dan RANKL diperlukan untuk diferensiasi dan aktivasi osteoklas yang diatur oleh OPG. Umpan balik dari RANKL akan menghambat resorpsi tulang. Ketidakseimbangan integritas jaringan tulang lebih disebabkan oleh aktivitas berlebihan dari resorbsi tulang seperti yang terjadi pada penyakit periodontitis apikalis dan marginalis. ${ }^{(8,28,37)}$

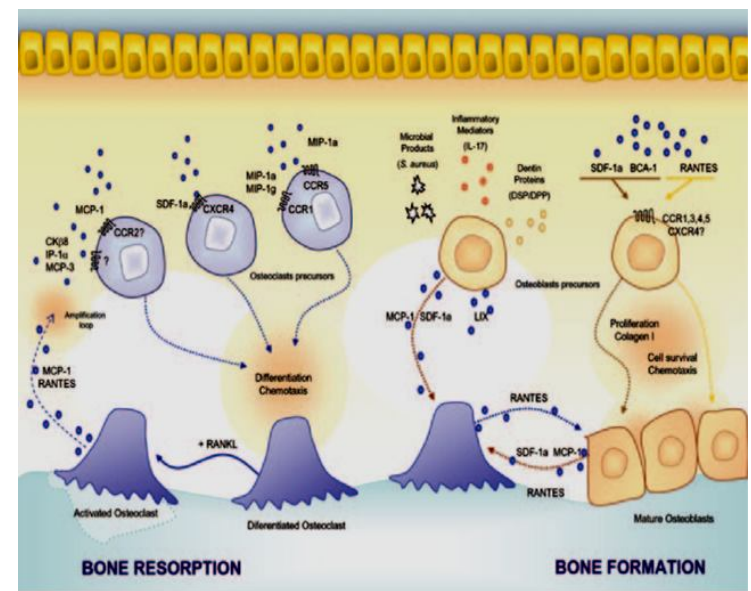

Gambar 6 : Kemokin reseptor di jaringan tulang (Silva, 2007)

Pada beberapa penelitian menyatakan

IL8 (CXCL1) dapat mengaktivasi dan mendorong prekursor osteoklas untuk berdiferensiasi melalui reseptor CXCR1 pada osteoklas demikian juga SDF1 (CXCL12) berinteraksi dengan CXCR4 dan MIP1(CCL3) berinteraksi dengan CCR1 dan CCR5 serta MCP berinteraksi dengan CCR2. Aktivitas RANKL pada osteoklas mature dapat mengiduksi MCP1 dan Rantes sehingga terjadi autokrin dan parakrin sinyal osteoklas untuk membuat prekursor oskeoklas berdiferensiasi. ${ }^{(13,28)}$

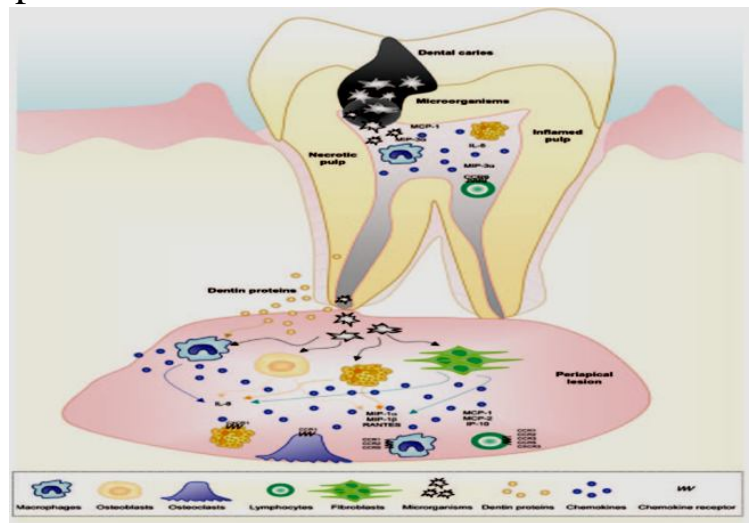

Gambar 7 : Kemokin Reseptor Di Jaringan Pulpa Gigi (Silva, 2007)

Pada osteoblas juga ditemukan reseptor kemokin CCR1, CCR3, CCR4, CCR5, 
CXCR1,CXCR3, CXCR4, CXCR5. Kemokin SDF1(CXCL12), BCA1(CXCL13) dan Rantes(CCL5) melalui reseptor diatas akan mengaktivasi proliferasi prekursor osteoblas menjadi osteoblas mature. Ada juga kemokin yang berasal dari osteoblast yaitu MCP1 dan SDF1 menyebabkan terjadinya crosstalk antar sel tulang setelah sel osteoblast tersebut di induksi oleh produk microba, mediator inflamasi dan protein dentin dimana terjadi perubahan sel osteoblas menjadi osteoklas dan sebaliknya kemokin Rantes menyebabkan crosstalk sel osteoklas menjadi osteoblast. ${ }^{(28)}$

\section{KEPUSTAKAAN}

1. Cawson R.A, Odell E.W. Oral Pathologi And Oral Medicine.10th Edition Churchill Livingstone Edinburgh. 2008. p 60-76

2. Fejerskov Ole, Kidd Edwina. Dental Caries The Desease And Its Clinical Managemen. 2nd Edition. Blackwell Munksgaard. 2008. p 3-6

3. Ryan, J., Kenneth. Sherris Medical Microbiologi An Introduction To Infections Deseases, Appleton \& Lange, Norwalk Connecticut. 1994. p 835-843

4. Bagg, Jeremy; Macfarlane, T. Wallace; Poxton, Ian R.; Smith, Andrew J.; Bagg, Simon. 2006, Essentials Of Microbiology For Dental Students, 2nd Edition, Oxford University Press. 2006.

5. Mooduto Latief. Immunopatogenitas Dan Perawatan Abses Periapikal Karena Infeksi Saluran Akar, Majalah Kedokteran Gigi Dental Journal, Kedokteran Gigi Unair. 2008. p 71-77

6. Slootweg.J.Pieter. Dental Pathology Apractical Introduction. Springer Berlin. 2007

7. Avery.K.James. Oral Development and Histologi. 3rd edition. Thieme Stuttgard. 2002

8. Orstavik Dag, Ford Pit Thomas. Essential Endodontology Prevention And Treatment of Apical Periodontitis. 2nd Edition. Blackwell Munksgaard. 2008.

9. Cohen Stephen, Hargreaves M Kennneth. Pathways Of The Pulp, 9th Edition, Mosby Elsevier. 2006
10. Selzer. Samuel, Bender I B. Dental Pulp. 3rd edition. Quintessence Publisher co. 2002

11. Harty S. Endodontics In Clinical Practice, 5th Edition, Wright Edinburgh.2004

12. WHO. Application Of The International Classification Of Diseases To Dentistry And Stomatognaty ICD-DA. 3rd Edition. WHO Library Cataloque Publication Data. 1995

13. Walker D M. Oral Mucosa Immunology : An Overview. An Acad Med Singapore. 2004. 33 suppl. p27-30.

14. Jontell M, Okiji, Dahlgren, Bergenholtz. Immune Defense Mechanisms Of The Dental Pulp, Critical Review In Oral Biology And Medicine.1998. p179-199.

15. Tronstad Leif. Clinical Endodontic, 2nd Revised Edition, Thieme, 2003

16. Hahn CL, Falkler WA Jr, Siegel MA. A Study Of T And B Cell In Pulpa Pathosis. J Endodontic. 1989. 15 p 20-26

17. Sakamoto M, Sanjo D. An Immunohistochemical Study On Human Dental Pulp In Different Depth Of Carious Lession. Jpn J Concerv Dent. 1992. 35 p 828-835

18. Izumi T, Kobayashi I, Okamura K, Sakai H. Immunohistochemical Study On The Immunocompetent Cells Of The Pulp In Human Non Carious And Carious Teeth. ArchOral Biol. 1995. 40 p 609-614.

19. Darwin Eryati. Imunologi dan Infeksi. Andalas University. 2006

20. Mosmann TR, Coffman RL. TH 1 And TH2 Cells: Different Patterns Of Lymphokine Secretion Lead To Different Functional Properties. Ann Rev Immunol. 1989. 7 p 145-173.

21. Mangkornkarn C, Steiner JC, Bohman R, Lindemann RA. Flow Cytometric Analysis of Human Dental Pulp Tissue. J Endodont. 1991. 17 p 49-53.

22. Sorg C. Heterogeneity In Subpopulations Of Macrophages. Molec Immunol. 1982. 19 p 12751280.

23. Adams DO, Hamilton TA. The Cell Biology of Macrophage Activation. Ann Rev Immunol. 1984. 2 p 283-318.

24. Dijkstra CD, Damoiseaux IG. Macrophage heterogeneity established by immunocytochemistry. Prog Histochem Cytochem. 1993. 27 p 1-65.

25. Ingle Jl, Langeland K. Etiology And Prevention Of Pulpal Inflammation, Necrosis And Dystrophy In Endodontics. Ingle JI, Taintor IF, editors. Philadelphia: Lea and Febiger, pp. 1985. p 304388.

26. Silva TA, Garlet JS, Fukada SY, Silva JS, Cunha FQ. Chemokines in Oral Inflammatory Diseases: 
Apical Periodontitis and Periodontal Disease. J DENT RES. 2007. 86 p 306-319

27. Nakanishi T, Takahashi K, Hosokawa Y, Adachi $\mathrm{T}$, Nakae $\mathrm{H}$, Matsuo $\mathrm{T}$. Expression Of Macrophage Inflammatory Protein 3 Alpha In Human Inflamed Dental Pulp Tissue. J Endod. 2005. 31 p 84-87.

28. Nair PN. Pathogenesis Of Apical Periodontitis And The Causes Of Endodontic Failures. Crit Rev Oral Biol Med. 2004. 15 p 348-381.

29. Chae P, Im M, Gibson F, Jiang Y, Graves DT. Mice lacking monocyte chemoattractant protein 1 have enhanced susceptibility to an interstitial polymicrobial infection due to impaired monocyte recruitment. Infect Immun. 2002. 70 p 3164-3169.

30. Silva TA, Lara VS, Silva JS, Garlet GP, Butler WT, Cunha FQ. Dentin sialoprotein and phosphoprotein induce neutrophil recruitment: a mechanism dependent on IL-1beta, TNF-beta, and CXC chemokines. Calcif Tissue Int. 2004. 74 p 532-541.

31. Yang LC, Huang FM, Lin CS, Liu CM, Lai CC, Chang YC. Induction of interleukin-8 gene expression by black-pigmented Bacteroides in human pulp fibroblasts and osteoblasts. Int Endod J. 2003. 36 p 774-779.

32. Murakami Y, Hanazawa S, Tanaka S, Iwahashi H, Yamamoto Y, Fujisawa S. A possible mechanism of maxillofacial abscess formation: involvement of Porphyromonas endodontalis lipopolysaccharide via the expression of inflammatory cytokines. Oral Microbiol Immunol. 2001. 16 p 321-325.

33. Kabashima H, Yoneda M, Nagata K, Hirofuji T, Maeda K. The Presence Of Chemokine And Chemokine Receptor In Inflamed Human Gingival Tissues. 2002. 20 p 70-77.

34. Zlotnik A, Yoshie O. Chemokines: A New Classification System And Their Role In Immunity.2000. 12 p 121-127.

35. Rossi D, Zlotnik A. The Biology Of Chemokines And Their Receptors. Annu Rev Immunol.200. 18 p 217-242.

36. Gemmell E, Carter CL, Seymour GJ. Chemokines In Human Periodontal Disease Tissues. Clin Exp Immunol. 2001. 125 p 134-141.

37. Boyle WJ, Simonet WS, Lacey DL. Osteoclast differentiation and activation. Nature. 2003. $423 \mathrm{p}$ 337-342. 